\title{
Reading in Public: Irene Longman and Citizenship
}

\author{
Kay Ferres
}

'Women who read, much more women who write, are, in the existing constitution of things, a contradiction and a disturbing element'

J.S. Mill 1869, 'The Subjection of Women' (145).

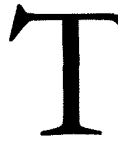

his essay describes the place of reading in the life of Irene Longman (1877-1962), the first woman elected to the Queensland parliament. ${ }^{1}$ personal life, fostered civic virtue and defined a realm of citizenship for newly enfranchised women. Its profile of Longman's public career highlights the connection between reading and rhetoric, the arts of persuasion and liberal democracy. It also draws attention to the importance of associational life in promoting women's public participation.

Trained as a teacher, Irene Bayley turned to journalism after her marriage to Heber Longman, and was active in women's organisations in Brisbane following her husband's appointment to the Queensland Museum. Longman's study of political ideas and social policy was an enterprise shared with other professional women through their affiliation with organisations like the Queensland Women's Electoral League (QWEL) and the National Council of Women (NCW). She used these networks to voice political ideas and to cultivate a public persona. As Linda Kerber has observed of America in this period, study and book discussion groups were key sites of women's intellectual development; there they discovered their abilities as orators and learnt how to use authority in public, not just private, settings (228).

Irene Longman's papers have not survived in the public archive, but her husband created a personal scrapbook, now in the collection of the Queensland Women's Historical Association. ${ }^{2}$ Heber Longman preserved

1 Biographical details are drawn from Patricia Fallon's M Phil thesis, So bard the conquering: A Life of Irene Longman (2002).

2 Irene Longman later added obituaries and other items relating to Heber's career. The Cutting Book is not paginated, and many items are undated. 
newspaper clippings, letters and Irene's notes from her many public speeches. Her first public appearances were as an advocate for the welfare of children, and for women's independent legal and economic status. She found a rich source of ideas in her wide reading of classical and contemporary literature, philosophy, the natural sciences and child psychology. The 'sparkling wit and repartee' that made her public meetings 'an intellectual treat' (Barker) owed a great deal to that reading.

In 1915, she gave an address, 'The Value of Literature', to the East Moreton Teachers Association, later published in the Queensland Education Journal. Describing the pleasures of reading and the public utility of literature, Longman also revealed something of her own taste. Noting that her talk could only 'touch the fringe of the wondrous fabric of the world's literature', she quoted Saint-Beuve to describe the pleasures she looked for in reading:

A true classic is an author who has enriched the human mind, who has really added to its treasure, who has got it to take a step further; who has discovered some unequivocal moral truth, or penetrated to some eternal passion in that heart of man where it seemed as though all were known and explored, who has produced his thoughts or his observation, or his invention under some form no matter what, so it be great, large, acute and reasonable, sane and beautiful in itself, who has spoken to all in a style of his own, yet a style which finds itself the style of everybody - in a style that is at once new and antique, and is the contemporary of all the ages. (6-7)

Longman also described literature's use value, identifying different reading communities and the benefits they derive from reading. Some of those communities comprise expert readers, who are also writers themselves: poets, philosophers, historians, scientists and social reformers. But the appeal of literature is wider: the circulating library, the availability of cheap books and the 'reading-made-easy' in popular magazines make the life of the imagination open to all. The reader demands only that the story-teller

Interest me somehow, anyhow; make me mindless of the room I am sitting in, of the people about me; soothe me, excite me, do what you like with me, only make it possible to keep reading on and to joy in doing so. (3)

Reading is also essential to the wider public good, producing a discriminating citizenry: 'Train me to become a citizen of the true Republic of letters, and I shall not be found on my knees before false gods, or trooping with the vulgar to crown with laurel brazen brows'. It develops taste and judgment. She promoted the appreciation of 'great books', saying that those who are taught them can 'find [their] own criticism of living poets' (6).

One of Longman's consistent themes was that literary study should be available to everyone; but she also highlighted the importance of such study in preserving the 'purity and dignity' of language. She summoned Milton and 
Pearsall Smith in support of her argument. From Milton, she took the idea that freedom from tyranny depended on care for language; and from Pearsall Smith the idea that living sounds, conveyed to us by the uninterrupted speech of countless generations' are at the core of a society's sense of itself. These connections have recently been reasserted in Adam Gopnik's study of Darwin and Lincoln, Angels and Ages. Following Pericles, Gopnik argues that language and oratory are crucial to democracy; that 'literary eloquence is essential to liberal civilisation':

Authoritarian societies can rely on an educated elite; mere mass society, on shared dumb show. Liberal cities can't. A commitment to persuasion is in itself a central liberal principle. New ways of thinking demand new kinds of eloquence. Our world rests on science and democracy, on seeing and saying; it rests on thinking new thoughts and getting them heard by a lot of people. (22)

Irene Longman and her associates promoted new thoughts about women and their roles in the family, work and politics. They were the new professionals, educated women who argued for social reform, changes to women's legal and economic status and the welfare of children. They participated in networks formed through reading and discussion groups in Australia and internationally, and used those connections to get their ideas heard more widely, before commissions of inquiry, in political meetings, and finally in the legislature.

Irene Bayley began her formal schooling at the age of nine. When her clergyman father moved to Queensland in 1889, the motherless Irene stayed in Sydney. Her development as an educational progressive began during her training as a kindergarten teacher at Maybanke College, where Maybanke Wolstenholme's syllabus blended Friedrich Froebel's educational theory with her own reading in theosophy. Wolstenholme, the founder of the Womanhood Suffrage League and editor of the Woman's Voice, was a friend of Cara and Edgeworth David, with whom Irene boarded while completing her education. The two women, together with Edgeworth David and his colleague Francis Anderson (whom Wolstenholme was later to marry), campaigned to reform teaching. They wanted teachers to be trained, registered and paid appropriately as professionals, and child development to be recognised as a discipline. The women were to become key figures in the administration of public education in New South Wales: David designed the syllabus for teacher training, and Wolstenholme became registrar of teachers.

In this environment, the young Irene's interest in science and literature flourished. The Davids, Wolstenholme and Anderson belonged to the Australasian Association for the Advancement of Science. The Andersons were pioneers of the Australasian Home Reading Union (AHRU), set up in Hobart in 1892. The AHRU aimed to develop 'a taste for recreative and 
instructive reading among all classes of the community and directing home studies to definite ends' (Roberts 145). Lyons has estimated that by 1893 there were over 100 reading circles and 2,218 members throughout Australasia, but comments that 'the AHRU tried in vain to interest the trade union movement in membership' ('Australasian' 388). Wolstenholme was disappointed by its failure to engage 'working folk'. By 1913, she was working with Anderson and Peter Board to establish the Workers' Educational Association (WEA). Tod Moore has shown how the WEA, through the textbooks it published for university extension courses, gave expression to Australian social liberalism in the 1920s and 1930s.

Wolstenholme promoted women's suffrage and political participation through the Woman's Voice. Lyons claims that the paper created an ideal community of woman readers', by prescribing a reading program for the 'New Woman'. This reading community 'was encouraged to concern itself with women's problems, which included, as their special responsibility, children's reading' ('Reading Models' 376). Longman took up Wolstenholme's political agenda: she pursued legal reforms that her mentor long advocated and she took a special interest in the education and welfare of children. In Queensland, she promoted these causes through her journalism and her involvement in community organisations.

Irene Bayley taught in schools in Sydney and Rockhampton before her marriage in Toowoomba in 1904. The marriage was to be an enduring partnership, though a childless one. For several years, the couple worked together on local newspapers. Heber was proprietor and editor of the Downs Post. This later became the Rag, with Longman as manager and George Essex Evans as editor. When Evans retired, the paper was renamed The Citizen. Irene contributed a Saturday feature for children, 'Talks with Aunt Tabitha'. Her column took the form of a letter, signed by 'your loving Aunt Tabitha'. It included stories and poems, riddles and other brain teasers. Competitions elicited entries from readers in Toowoomba, the Darling Downs and Brisbane. She encouraged children to engage in nature study and astronomy and to participate in community events. Excerpts and adaptations of children's stories were a regular feature. Aunt Tabitha alerted her readers to new and interesting books, and introduced them to Australian authors such as Jeannie Gunn.

In adopting the 'aunt' persona, Longman modelled a civil public discourse. She was at once friendly and impersonal. Her talks generally did not refer to family life; instead she assumed that her readers' interests lay in the spaces of sociability between home and school. She addressed them as citizens in the making. Explaining the editor's decision to cut the column during an election campaign, she told them:

Last week the Editor had so much to say to the big folks about the elections that he could not spare even one column for our letter. It was a pity, but still 
we know how important it is to try to send the very best men into Parliament, and so we will not grumble. I hope, however, that you missed our chat and felt a little sorry, just as we like to think our friends miss us when we are away. ('Talks' 1908)

Although she avoided direct social commentary, Longman occasionally delivered moral lessons about human dignity. A story about a slave who rescued a man from a burning church tower is indicative of her style. She describes the slave's refusal of a reward for his valour:

As a rule the whites had no praise for their slaves and looked upon them as animals and often treated them worse. Now this slave, this hero, turned to the Mayor and said, 'You may keep your gold! I scorn it. But tell me if the deed I have done is not the deed of a MAN, although you treat me as a slave?' And that very night he was given his liberty and became a free man. That was long before slavery was done away with, but as you know that came later on. ('Talks' 1907)

Longman's rhetorical style replicates features of Ciceronian conversation, as described by Gary Remer. This conversation is private, philosophical and elitist. Its purpose is not action, but interaction: it incorporates interlocutors in a common fellowship. It pursues an inquiry into abstract moral questions, using speech that is 'serene and restrained'. Such talk does not seek to persuade, but to encourage thoughtful reflection. Longman does not condescend to her readers, but shares her knowledge of a wider world with them and encourages them to take their place in that world.

In 1913, Longman became secretary of the Playground Association of Queensland (Wood 196), whose local champion was Josephine Bedford. Bedford and her companion Lilian Cooper, the first woman to practice medicine in Queensland, had extensive international networks. They were delegates to the International Council of Women in Stockholm in 1912 and visited the USA in the same year, attending lectures on public playgrounds for children at Berkeley and observing work aimed at social amelioration in a number of cities. Bedford was especially influenced by the architects and social planners Arthur and Lorna Leland, and Frederick Law Olmstead, the designer of many early playgrounds, and of Central Park. Her association with Bedford expanded Longman's intellectual horizons. Together, Bedford and Longman read papers at an NCW meeting in June 1913. The minutes record that Longman's subject was 'Science and Play', Bedford's 'Playgrounds'. With the NCW's support, they approached municipal councils, acquired land and secured planning approval for the first free supervised playground and a free children's library, established in Paddington in 1918.

Longman sought practical ways to supply books to those of limited means and unlimited desires'. She was a foundation member of the Bush 
Book Club in 1921. Modelled on a similar club in NSW, the Queensland Bush Book Club was an association of women:

near enough to the pioneering days to know something of the loneliness of the bush.... We were non-sectarian and non-political always, our aim was to give something to the lives of the men and women whose work is of national importance in Australia. Booklovers being a fellowship the world over, we felt that we in the cities could give the country people what we obtain so much more easily than they in their remoteness. (Fryer MS F1528)

Books were distributed to paying subscribers and to lighthouses, prison farms and other institutions for free. In the busiest years, up to 3,000 books and magazines were in circulation.

Irene Longman championed reading because she thought it fostered the kind of democratic character that a new national community required. In Brisbane, the Longman house became a meeting place of friends and visiting colleagues. The couple belonged to clubs and societies that promoted the discussion of ideas. Heber was a member of the Philosophy Circle and the Thirty Club; Irene of the Lyceum Club. Together the couple built an impressive library. Irene had described the pleasures of collecting books to her audience of teachers in 1915, remarking on the way that a library reflects its owner's personal history and values: 'Those masterpieces were bought with the price of a new winter's coat. That faded little book of poems went with us on a holiday tramp' (5). In his memorial to Heber Longman, D.A. Herbert described the shared interests on display in the Longmans' library: 'science, history, philosophy, biography, great literature, drama and not least among them, poetry' (88).

Irene Longman was a regular speaker at the Lyceum Club, founded in 1919 by the 'eccentric suffragette' Margaret Ogg for women interested in the advancement of literature, journalism, science, art and music. There she discussed books that influenced her thinking. She was also a member of the Syllabus Committee of the NCW, where she organised a program of speakers and papers on topics such as architecture and town planning, public health, the suffrage movement, legal issues, sex education and the WEA. Edith Cowan was among these speakers. Longman was President of the NCW for four years from 1921, during which time she argued for women to be included in Australia's delegation to the League of Nations, pressed for the appointment of a woman to the Commonwealth Film Censorship Board, and advocated for special educational provision in state schools for children who were 'mentally deficient'.

After Longman's election, the Brisbane Courier's women's editor, Winifred Moore, paid tribute to her success in creating harmony among the more than fifty societies affiliated with the NCW. Moore, who wrote a 
regular column that canvassed public issues and politics, called the NCW 'the Women's Parliament', a reference to the meeting place of the Women's Social and Political Union (WSPU) in London. Moore was confident that Longman would be effective in parliamentary debate, as her experience had augmented her 'natural gifts of clear thinking and plain speaking' with 'those qualities of tact and graciousness which are even more necessary in public than in private life.' In an election leaflet, Longman drew attention to her public welfare work, and claimed that 'there can be no true democracy where only one sex is directly represented in parliament'. She pledged to be 'a crusader for women'. As she saw it, women could only benefit from the franchise if they secured economic independence as workers, whether in the home or in paid employment. Women's dependence on men was an impediment to their full participation as citizens. It was a view put forcefully by J.S. Mill in 'The Subjection of Women': that women's economic dependence on men was slavery in a milder form, a condition that has not lost the taint of its brutal origin'. Mill's essay had been republished in 1912 with an introduction by the suffragist Millicent Garrett Fawcett. It seems likely that Longman knew it well, as her account of the legal and economic disabilities that women faced closely resembled Mill's. But like the WEA intellectuals, her aim was to expand citizenship, not to promote 'sex antagonism' and class conflict.

To redress economic inequality, Longman argued for equal pay for equal work and for a wage for mothers. In a debate at the Brisbane Women's Club in March 1928, she outlined the case for motherhood endowment, while her appearance at the Brisbane hearing of the Royal Commission on Child Endowment in the same year caused a stir. The NCW's submission proposed changes to industrial arbitration laws to recognise women as workers and to grant equal pay for the same work. They also proposed that the Commonwealth should recognise the work of mothers and the value of children to the nation through a wage payment. The import of the NCW proposal was not lost on the Commissioners, who asked Longman:

Women could live apart from their husbands? That is an alteration of existing conditions?

Yes, absolutely. It is revolutionary, and that is what we wish. (Lake 105-06).

Longman's attraction to radical ideas was also evident in her talk on 'Some Woman Rebels' to an exclusively male audience at the Constitutional Club in July 1929, in which the new MLA signalled her reform agenda. Her subjects were 'women who revolted against evil conditions and false conventions' to secure a new social order: Mary Wollstonecraft, Florence Nightingale and Emmeline Pankhurst. Barbara Caine has observed that, for women in the 1920s, who still faced obstacles to full participation in public life, Wollstonecraft's ideas were 'alive and irritating' (317) and her Vindication of the 
Rights of Woman was on the Woman's Voice reading list. Longman reminded her audience of the Vindication's argument that women's rights included a right to be admitted to the professions, and economic independence for married women. She restated Wollstonecraft's claim that 'women's duty to themselves was to be rational beings and good citizens' (qtd in 'Women "Rebels").

Longman's third subject was Emmeline Pankhurst, who had died the year before, poignantly in the year that the parliamentary vote was finally accorded to all women in Britain. Pankhurst was an exemplary feminist for Longman, and also a dangerous one, adopting militant tactics that saw her imprisoned. She incited violence and used the dock as a political platform, arguing that the Suffragettes should be treated in the same way as Irish rebels, serving their sentences as political prisoners, not as common criminals. Yet Longman had an enduring admiration for Pankhurst. In 1960, disappointed that other women had not followed her into the Queensland parliament, she published 'A Woman's Dream' in the women's pages of the New Age. The ghostly presence of Mrs Pankhurst ponders this failure:

Australia is known the world over as the place where women are content to let all the important questions of their vast and growing continent be decided by men. Why, I wonder, is it that so few Australian women feel it their duty to take part in Government? They have a reputation for success in literature, in music, in business, in humanitarian and such-like societies and yet pass by the very means by which these ends could be more readily obtained.

But giving her speech at the Constitutional Club, the newly elected Longman also kept her distance from Pankhurst, a proponent of social purity, who attacked men for sexual incontinence. In her Address in Reply at the opening of the new parliament in August 1929, Longman repudiated 'sex antagonism' and stressed that she wanted to work co-operatively with her male colleagues in government.

Reflecting on her short term in office in an address to QWEL in 1950, Longman listed her achievements: securing separate accommodation for the Children's Court, removing it from the 'sordid and harmful surroundings of the Police Court'; and the appointment of two women to the Queensland police force. She also secured improvements to women's status in marriage, introducing changes to probate provisions that had previously disadvantaged widows and addressing anomalies in state based divorce laws.

Although she always called attention to women's interests, many of Longman's parliamentary speeches addressed larger issues of social welfare, health provision, economics and unemployment relief. She was also prominent in debates on censorship and access to books. Her opportunity to speak on these matters came with the introduction of the Vagrants, Gaming and Other Offences bill in November 1931. The bill was broadly concerned 
with police powers to regulate public morality: the 'other offences' it referred to included prostitution and the publication and distribution of obscene material. Longman was ambivalent about increased police powers, and she was concerned to ensure that they should not be abused when it came to books, though she had a different view of visual material:

In the past a great deal of harm has been done by the unwise censorship of books. Most of us are familiar with the long list of books which are at present prohibited from entering the Commonwealth. I have been rather interested in finding that some of them have found a resting place-probably before the censorship was imposed - on the shelves of our own [parliamentary] library. I have no intention of mentioning the names of those books, otherwise the quiet of the upper library might be somewhat disturbed—but that list includes numerous old classics, and although only the cheap paper-covered editions are proscribed, that seems to me to be taking unfair advantage of students who have not sufficient money to spend on the expensive and de luxe editions of these works. It is rather unfair that those of us who are interested in literature and have not sufficient money to spend on the finest editions should be debarred from acquiring the cheaper ones. At any rate, the provisions dealing with the censorship of obscene postcards and photographs are essential. I hope that the powers will not be abused by police, and that the Minister will see to it that a sane and rational procedure is adopted in this matter. It seems to me most extraordinary that very often men should be appointed as censors who have no conception of the beauties of literature or of the great wealth that is to be found in the old and modern classics. (QPD 160: 1746)

Longman's concerns about censorship dated back to her time as President of the NCW. She was disturbed by cinema advertising, with its 'lurid appeals to degraded instincts' and argued, in a letter to Prime Minister Hughes, that women should 'share in the responsibility of guiding to some extent this great force which today is exercising so powerful an influence in the life of the people' (NCW Minute Books 1921). Hughes disagreed that women brought any special expertise or sensibility to the work of censorship, and pointed out that the Commonwealth had no jurisdiction over advertising. The Royal Commission on the Moving Picture Industry, which reported in 1928, took a different view. It recommended that the Film Censorship Board include a woman and that it should be empowered to regulate advertising. The Commissioners thought that 'worldliness' was a necessary qualification for membership of the Board, and did not see gender as a disqualification. It seems Longman was galled by Hughes's dismissal of her case. When her opportunity came to speak about censorship in Parliament, she commented that it was time a woman was heard on these issues, as 'women had been excluded from any political decision making regarding the censorship of literature on the assumption that intellectual ability was the province of men' (QPD 160: 1796). 
At the second reading of the Bill, Longman spoke against an amendment that would 'cloud the issue' of obscenity in relation to medical books and treatises on sexuality. She did not want such books banned. As examples, she cited Geddes and Thompson's 'very interesting little book Sex' and Arthur Keith's The Human Body, both works that should be available for 'the average person' to read. She spoke in favour of a provision that would prohibit the publication of photographs in divorce and sexual cases. Here Longman was drawing the limits of freedom of speech: what the newspapers saw as 'spicy items' were to her intrusions on privacy that could not be justified by public interest.

Longman revisited these issues in debate on the Judicial Proceedings (Reports and Regulations) bill. Her target was newspaper reports of divorce cases. She argued that the press should not be free to publish the details of evidence in divorce trials, and to exploit misfortune and distress, as was currently the case:

One has only to go back to Nathaniel Hawthorne's The Scarlet Letter and remember how people were pilloried and persecuted because of their domestic and private relationships to know that it is a very far cry from that time to the attitude of mind which leads to the introduction of this measure. (QPD 160: 2392)

She was taunted in the House as 'Mrs Grundy', and as she recalled in 1950, her success was short-lived. 'Certain sensational, scavenger newspapers' were not pleased that they could not publish 'intimate details of domestic tragedies' ('Speech'). Their influence saw the act repealed when Labor returned to office.

Longman made a study of government, and believed that its aim should be the ideal social organisation of the state. She deplored politicians' preoccupation with 'the art and science of getting and keeping office'. In Parliament, Longman spoke against party politics and condemned both sides' adherence to 'old ideas and modes of thought that are mildewed with time'. She declared:

A deliberative Assembly, if it is composed of trained and educated minds, should be able to deal with these problems and come to some solutions that will be for the betterment, not only of our own state and country, but also of the world in general. (QPD 159: 228)

She elaborated her ideas about government during her second campaign, when she took part in a panel discussion at the Brisbane Women's Club. Her talk, titled 'Tomorrows', contrasted the futures imagined in contemporary science fiction with a philosophical tradition of utopian thinking. She cited Plato, More, and Rousseau and the English political theorist James Harrington in a discussion of government, and Bellamy, Butler, Wells, Shaw and Verne in comments about the benefits of scientific advancement. New communications have created a world that is a 'whispering gallery', but amidst this expansion 
of knowledge, she asserted, 'the science of human relationships, of national relationships, seems to have lagged sadly behind'.

Longman's candidature in 1929 attracted wide public interest and support. A Telegraph editorial endorsed her, saying 'She has culture, intelligence and a true sense of citizenship'. As the Depression deepened and unemployment grew, the Moore government's hold on power soon weakened. Longman's popularity waned. She was attacked for her ideas about economic restructuring and her opposition to 'palliatives and doles'. Australian Labor Party State organiser Joseph Collings publicly castigated her for 'cruel utterances' on economic management in the home, drawing attention to her own childlessness:

Here in sunny Queensland, one of the richest countries on earth, with a prolific harvest of all Nature's life-sustaining products, and she, childless, coolly talks, in a superior way, from her vantage ground of culture and economic independence down to the common working class of how to 'manage' on 18 s a week. Father, mother, and child! How to 'manage'! This, and Christmas upon us-the season of goodwill. How to 'manage' on 18s a week! Three souls, and in her lovely home there are hundreds of shillings weekly for two.

During the campaign, she confronted unruly crowds at public meetings. Her dignity and civility could not match 'organised disorder' in a crowd of 2000 at the Avro Theatre. The Courier reported her 'brave stand':

During her three years in Parliament Mrs Longman made many fluent, logical and humane speeches that commanded the attention and respect even of those on the Opposition benches, but last night her words could not have been heard beyond a few rows of the front seats. There was no chance even of answering interjections- the volume of noise was merely that of obstruction and inanity. (Harrison)

On the same day, the Telegraph decried the 'shameful display' with a cartoon, showing Longman in the grip of an outsized figure labelled 'Rank Hooliganism'. She dangled in his powerful grip, her mouth covered by his large hand. Unlike the floor of the Legislative Assembly, the public sphere of electoral politics was a scene of 'continuous uproar' that drowned Longman out. Her culture and class counted against her, and her civility and refinement could not compete with rowdy dissent. In her post-parliamentary life she turned to radio to promote the causes that mattered to her: peace, women's citizenship and greater participation in politics.

\section{WORKS CITED}

Barker, Arthur. 'Bulimba Electorate. To the Editor.' Brisbane Courier 19 Apr. 1929: 18. Caine, Barbara. Bombay to Bloomsbury: A Biography of the Strachey Family. Oxford: Oxford UP, 2005. 
Collings, Joseph. Letter. 'Mrs Longman Challenged.' Daily Standard 22 Dec. 1930: 6.

Fallon, Patricia. So hard the conquering: A Life of Irene Longman, M Phil thesis, Griffith University, 2002.

Gopnik, Adam. Angels and Ages: A Short Book about Darwin, Lincoln and Modern Life. London: Quercus, 2009.

Harrison, G. 'Wild Scenes. Mrs Longman's Brave Stand.' Brisbane Courier 13 May 1932: 13.

Herbert, D.A. 'Memorial Lecture: Heber Albert Longman.' Proceedings of the Royal Society of Queensland 66.7 (1954): 83-89.

Irene Longman Cutting Book, Queensland Women's Historical Association, Miegunyah, Bowen Hills, Brisbane.

Kerber, Linda K. Toward an Intellectual History of Women. Chapel Hill: U of North Carolina P, 1997.

Lake, Marilyn. Getting Equal: The History of Australian Feminism. Sydney: Allen and Unwin, 1999.

Longman, Irene. 'The Value of Literature'. Queensland Education Journal (April 1915): 1-7.

—. 'Speech to the Queensland Women's Electoral League' 12 July 1950. Manuscript. Collection, John Oxley Library, State Library of Queensland, VF 922.2 Lon.

—. 'Talks with Aunt Tabitha.' Citizen 17 Aug. 1907: 2.

—. 'Talks with Aunt Tabitha.' Citizen 8 Feb. 1908: 2.

—. 'Woman's Dream.' New Age 31 Mar. 1960: 6.

Lyons, Martin. 'The Australasian Home Reading Union, 1892-97.' A History of the Book in Australia 1891-1945. Ed. Martyn Lyons and John Arnold. St Lucia: U of Queensland P, 2001. 386-88.

_- 'Reading Models and Reading Communities.' A History of the Book in Australia 1891-1945. Eds Martyn Lyons and John Arnold. St Lucia: U of Queensland P, 2001. 370-82.

Mill, J.S. 'The Subjection of Women.' 1869. On Liberty and Other Writings. Ed Stefan Collini. Cambridge: Cambridge UP, 1995. 117-217.

Moore, Tod. 'A Civic Order'. What Were They Thinking? James Walter and Tod Moore. Sydney: U of New South Wales P, 2010. 133-73.

Moore, Winifred. 'The Passing Show.' Brisbane Courier 2 May 1929: 10.

National Council of Women Minute Books. John Oxley Library, State Library of Queensland. MS 7266.

Queensland Bush Book Club. Papers 1921-1967. Fryer Library, University of Queensland, MS F1528.

Queensland Parliamentary Debates (QPD) 1931, Vol. 159.

Queensland Parliamentary Debates (QPD) 1931, Vol. 160.

Records of the Queensland Women's Electoral League 1903-1967. John Oxley Library, State Library of Queensland. MS43061.

Remer, Gary. Political Oratory and Conversation: Cicero versus Deliberative Democracy.' Political Theory 27.1 (1999): 39-64.

Roberts, Jan. Maybanke Anderson: Sex, Suffrage and Social Reform. Sydney: Hale and Iremonger, 1993. 
'Women "Rebels". Work for Humanity. Mrs Longman Praises Three Great Personalities.' Brisbane Courier 5 July 1929: 16.

Wood Anne. 'The Evolution and Growth of Women's Organisations in Queensland 1859-1958.' Royal Historical Society of Queensland Journal 1.1 (Sept. 1959): 184 213.

Copyright of Full Text rests with the original copyright owner and, except as permitted under the Copyright Act 1968, copying this copyright material is prohibited without the permission of the owner or its exclusive licensee or agent or by way of a license from Copyright Agency Limited. For information about such licences contact Copyright Agency Limited on (02) 93947600 (ph) or (02) 93947601 (fax) 